\title{
A rare case of basilar impression
}

\author{
Rajesh Verma, ${ }^{1}$ Vivek Junewar, ${ }^{1}$ Ravindra Kumar Garg, ${ }^{1}$ Hardeep Singh Malhotra ${ }^{1}$
}

1Department of Neurology, Chhatrapati Shahuji Maharaj Medical University, Lucknow, Uttar Pradesh, India

Correspondence to Professor Rajesh Verma, drrajeshverma32@yahoo.com

\section{Summary}

A teenage girl presented with progressively worsening neck and occipital pain since 8 months ago that was associated with restriction of neck movements, low to moderate grade fever, anorexia and weight loss followed by gradually progressive quadriparesis since 3 months ago. Neurological examination revealed spastic quadriparesis without cranial nerve palsy. MRI of the cervical spine revealed prevertebral and paravertebral abscess from clivus to C2/C3 level, which extended into the anterior epidural space at C1-C3 level, causing atlantoaxial dislocation. There was evidence of basilar invagination. The dislocated dens caused compression over the cervicomedullary junction. On this basis, a diagnosis of craniovertebral junction Pott's disease was made. The patient was given neck immobilisation with cervical collar, and antitubercular treatment was started. She showed significant improvement in her neurological deficit during follow-up.

\section{BACKGROUND}

Pott's disease (tuberculosis of the spine) is one of the important manifestations of extrapulmonary tuberculosis. The craniovertebral junction (CVJ) Pott's disease is rare, accounting for less than $1 \%$ of all cases. Atlantoaxial dislocations (AAD) are the most common abnormality seen in CVJ Pott's disease. CVJ tuberculosis rarely causes basilar impression. Basilar impression is an acquired type of basilar invagination. It is usually seen in diseases such as rickets, osteogenesis imperfecta, hyperparathyroidism, Hurler's syndrome, Paget's disease and acro-osteolysis (Hajdu-Cheney syndrome). It is believed that the bone and soft tissue involvement by the tuberculous process at the CVJ results in basilar impression. To the best of our knowledge, cases of tuberculosis as a cause of basilar impression have been rarely reported so far. This case highlights the importance of suspicion of tuberculous aetiology, especially in young patients with a chronic history of neck pain and with findings suggestive of high cervical compressive myelopathy.

\section{CASE PRESENTATION}

A 17-year-old, previously healthy, girl presented with progressively worsening neck and occipital pain since 8 months ago that was associated with restriction of neck movements. The pain was aggravated on movement of the neck and was relieved by rest. It was associated with low to moderate grade fever along with anorexia and weight loss. She then gradually developed progressive quadriparesis over the last 3 months. This was followed by dysphagia and vomiting for the last 15 days. There was no contact history with other patients with tuberculosis. General examination did not reveal any significant findings except for tenderness over the cervical spine and restricted neck movements in all directions. There was no lymphadenopathy and the neck height ratio was within normal limits. Neurological examination revealed quadriparesis with a bilateral extensor plantar response. There was no evidence of cranial nerve palsy and the sensory examination was normal.

\section{INVESTIGATIONS}

Laboratory examination was normal except for raised erythrocyte sedimentation rate. The chest x-ray did not reveal any abnormality. Cervical spine radiograms reveal $\mathrm{AAD}$ with basilar invagination (figure 1). MRI of the cervical spine revealed prevertebral and paravertebral abscess from clivus to $\mathrm{C} 2 / 3$ level, which extended to lateral recess and neural foramina at $\mathrm{C} 1 / 2$ level, causing compression over exiting nerve roots, and also extended into the

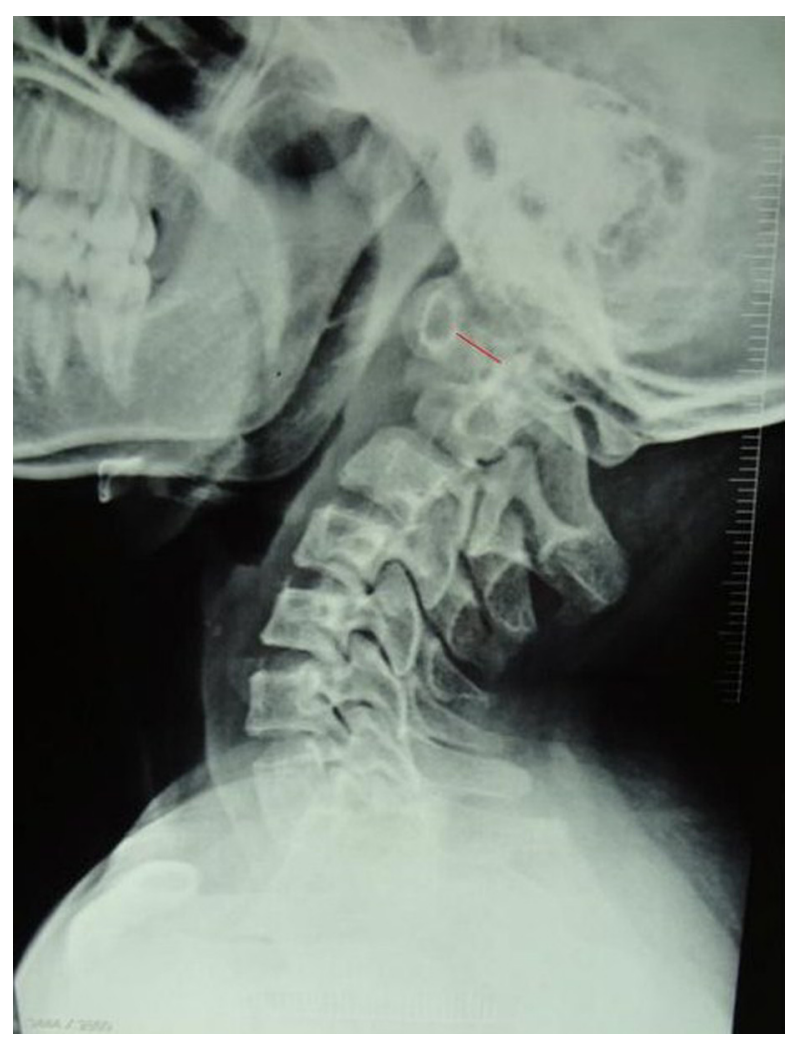

Figure 1 Radiogram lateral view of cervical spine, showing atlantoaxial dislocation. 


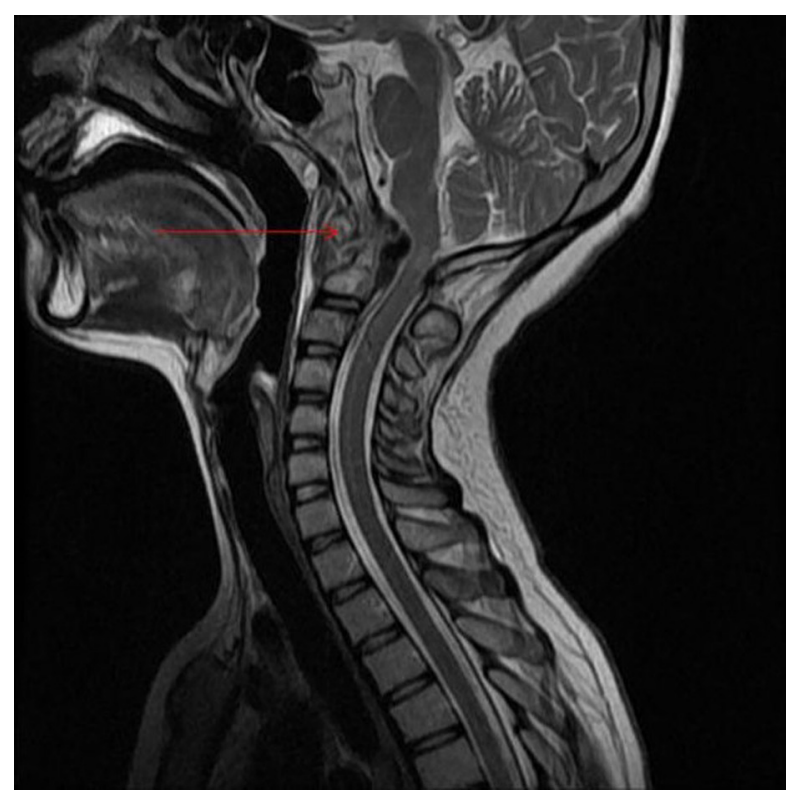

Figure $2 \mathrm{MRI}$ of the cervical spine, showing prevertebral abscess.

anterior epidural space at $\mathrm{C} 1-\mathrm{C} 3$ level, causing $\mathrm{AAD}$ (figure 2). There was basilar invagination with tip of dens significantly extending above Chamberlain's line (figure 3). The dislocated dens along with the epidural collection and thickened anterior longitudinal ligament caused compression over the cervicomedullary junction with signal intensity alterations within the cord. A vertebral biopsy was planned but could not be done as the relatives did not give consent for the invasive procedure.

\section{DIFFERENTIAL DIAGNOSIS}

On this basis, a diagnosis of secondary CVJ anomaly with atlantoaxial dislocation and retropharyngeal abscess probably caused by Pott's disease was kept.

\section{TREATMENT}

The patient was given neck immobilisation with cervical collar, and antitubercular treatment (ATT) was started.

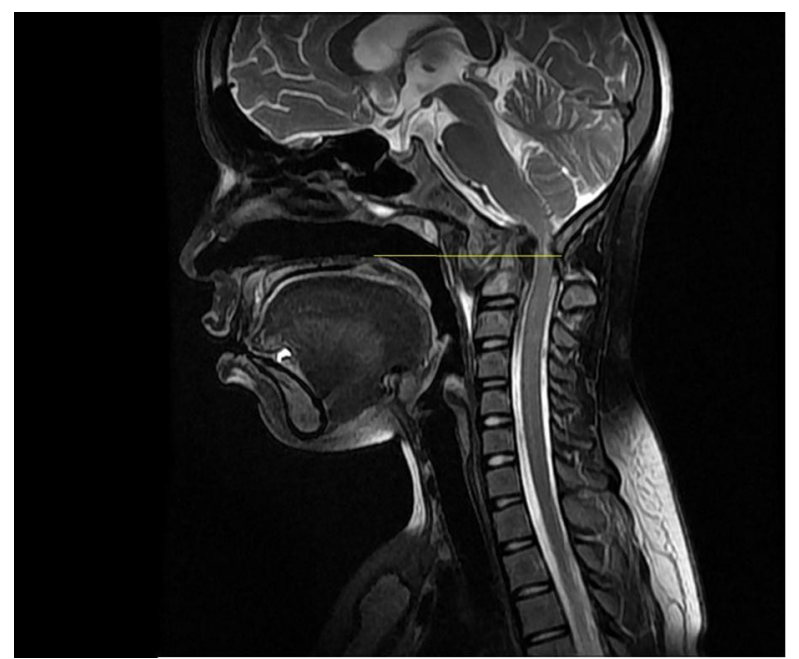

Figure 3 MRI of the cervical spine, showing basilar invagination. The horizontal yellow line depicts Chamberlain's line.
ATT consisted of daily doses of Isoniazid ( $5 \mathrm{mg} / \mathrm{kg}$ ), Rifampicin (10 mg/kg), Ethambutol $(15 \mathrm{mg} / \mathrm{kg})$ and Pyrizinamide $(15-30 \mathrm{mg} / \mathrm{kg})$. All the four drugs were given for the first 2 months after which Isoniazid and Rifampicin were advised to be continued for the next 7 months. A neurosurgeon's opinion was sought, who advised conservative management in view of mild compressive myelopathic changes. The patient was discharged and advised to be under regular follow-up.

\section{OUTCOME AND FOLLOW-UP}

During regular follow-up for the last 6 months, the patient showed a significant improvement in her neurological deficit. She is still on ATT and is under regular follow-up.

\section{DISCUSSION}

Pott's disease (tuberculosis of the spine) is one of the important manifestations of extrapulmonary tuberculosis and constitutes about $6 \%$ of all cases of extrapulmonary tuberculosis. Most commonly, Pott's disease involves the thoracic spine. Cervical spine involvement is less common, constituting $10 \%$ of all cases of Pott's disease. The CVJ Pott's disease is still rarer and accounts for less than $1 \%$ of all cases. ${ }^{12}$

$\mathrm{AAD}$ are the most common abnormality seen in the CVJ Pott's disease. ${ }^{3}$ CVJ tuberculosis can lead to $\mathrm{AAD}$ by two mechanisms: (1) osteomyelitis and (2) destruction of the ligaments, mainly the transverse and alar. ${ }^{1}$ It is suggested that CVJ tuberculosis results from the spread of infection from the retropharyngeal tissues to the bony elements; primary infection of the atlas or axis is rare. Eventually, the infection causes destruction of the bony and ligamentous structures, leading to cervicomedullary neural compression and occipitocervical and/or atlantoaxial instability. ${ }^{4}$ The occipito-atlantoaxial complex accounts for about $80^{\circ}$ rotation and significant flexion. Destruction of this complex results in abnormal translational and rotational movements. ${ }^{5}$ Atlantoaxial instability and abscess can be present together. Abscess can cause lower cranial nerve palsies or spinal nerve root compression, leading to occipital headaches and paraesthesia. Mechanical obstruction from a retropharyngeal abscess can cause dysphagia and airway compromise. ${ }^{1}$ The patient may show constitutional symptoms such as fever, anorexia and weight loss as in our case. However, these occur only in approximately $40 \%$ of patients with spinal tuberculosis. It is therefore important not to exclude spinal tuberculosis when constitutional symptoms are not present.

There is basilar impression along with the $\mathrm{AAD}$ in this case. Basilar impression is an acquired type of basilar invagination. It is seen in diseases such as rickets, osteogenesis imperfect, hyperparathyroidism, Hurler's syndrome, Paget's disease and acro-osteolysis (Hajdu-Cheney syndrome) (table 1). It is believed that the bone and soft tissue involvement by the tuberculous process at the CVJ results in the basilar impression. To the best of our knowledge, cases of tuberculosis as the cause of basilar impression have rarely been reported so $\mathrm{far}^{3} 6$

CVJ tuberculosis predominantly affected the anterior structures and, hence, the transoral approach is accepted as the method of choice for biopsy of lesions as well as 
Table 1 Classification of craniovertebral junction abnormalities

\begin{tabular}{ll}
\hline Congenital anomalies/malformations & $\begin{array}{l}\text { Developmental/acquired } \\
\text { abnormalities }\end{array}$ \\
\hline $\begin{array}{l}\text { A. Malformations of the occipital bone } \\
\text { 1. Manifestations of occipital }\end{array}$ & $\begin{array}{l}\text { A. Abnormalities of foramen } \\
\text { magnum }\end{array}$ \\
$\begin{array}{ll}\text { a. Clivus segmentation } & \text { 1. Secondary basilar invagination } \\
\text { b. Remnants around foramen } & \text { a. Paget's disease } \\
\text { magnum } & \text { b. Osteomalacia } \\
\text { c. Dens segmentation anomalies } & \text { c. Rickets } \\
\text { 2. Condylar hypoplasia } & \text { d. Rheumatoid arthritis } \\
\text { 3. Basilar invagination } & \text { e. Osteogenesis imperfecta } \\
\text { B. Malformations of the atlas } & \text { f. Hyperparathyroidism } \\
\text { 1. Atlas assimilation } & \text { g. Acro-osteolysis } \\
\text { 2. Aplasia of arches of atlas } & \text { h. Hurler's syndrome } \\
\text { 3. Atlantoaxial fusion } & \text { i. Tuberculosis } \\
\text { C. Malformations of the axis } & \text { 2. Foraminal stenosis } \\
\text { 1. Dens dysplasia } & \text { a. Achondroplasia } \\
\text { a. Os odontoideum } & \text { B. Atlantoaxial instability } \\
\text { b. Ossiculum terminale } & \text { 1. Morquio syndrome } \\
\text { persistens } & \text { 2. Down syndrome } \\
\text { 2. Irregular atlantoaxial } & \text { 3. Inflammatory } \\
\text { segmentation } & \text { a. Rheumatoid arthritis } \\
\text { 3. Segmentation failure of C2-C3 } & \text { 4. Infections } \\
& \text { a. Grisel syndrome } \\
& \text { 5. Traumatic } \\
& \text { 6. Tumours } \\
\text { a. Neurofibromatosis } \\
\text { b. Syringomyelia }\end{array}$ \\
&
\end{tabular}

decompression of the neuroaxis. ${ }^{1}$ Positivity of smear and culture for bacilli has been reported to be present in less than $50 \%$ of cases. Approximately $75 \%$ of cases have shown granulomatous tissue with or without caseation necrosis on histological study. Sensitivity of the PCR test for Mycobacterium tuberculosis ranges from $91.4 \%$ to $97.6 \%$. Specificity is high $(99.5-100 \%){ }^{5}$

The treatment options for the CVJ tuberculosis have been controversial, from an absolutely conservative approach to radical extirpation. ${ }^{4}$ This inconsistency is mainly due to the absence of well-proposed guidelines. Also the symptomatic or radiological features are diverse enough to justify several definite treatment modalities. Many authors favoured antituberculous medication with or without external immobilisation in the case of minimal bone destruction and minimal neurological deficit. Surgical treatment may be required when there are neurological symptoms due to cord compression or a significant degree of instability, $\mathrm{AAD}$ or bone destruction. Many authors recommend posterior fusion and fixation and/or anterior decompression, especially when anterior cord compression or irreducible $\mathrm{AAD}$ existed. ${ }^{6}$ Owing to the presence of minimal neurological deficits in our case, the patient was subjected only to conservative treatment and showed improvement with it.

\section{Learning points}

- This is one of the rare cases with tuberculosis as the cause of basilar impression.

- This case highlights the importance of suspicion of tuberculous aetiology, especially in young patients with a chronic history of neck pain and with findings suggestive of high cervical myelopathy.

- Conservative line of management with antitubercular treatment still has a role in mild neurological deficits in cases of craniovertebral junction Pott's disease.

\section{Competing interests None.}

Patient consent Obtained.

\section{REFERENCES}

1. Kotil K, Dalbayrak S, Alan S. Craniovertebral junction Pott's disease. Br J Neurosurg 2004;18:49-55.

2. Sarda DK, Kothari $P$, Adivarekar $P$, et al. Atypical presentation of tuberculosis. Indian J Tuberc 2006:53:223-6.

3. Hong J-M, Lee S-G, Park C-W, et al. Tuberculosis of the craniovertebral junction with basilar impression-a case report. Korean J Spine 2010;7:103-6.

4. Lifeso R. Atlantoaxial tuberculosis in adults. J Bone Jt Surg 1987;68:183-7.

5. Lee DK, Cho K-T, Im S-H, et al. Craniovertebral junction tuberculosis with atlantoaxial dislocation: a case report and review of the literature. $J$ Korean Neurosurg Soc 2007;42:406-9.

6. Daniel RT, Rajshekhar V. Tuberculosis causing secondary basilar impression. Case illustration. J Neurosurg (Spine 2) 1999;90:276.

7. Bhojraj SY, Shetty N, Shah PJ. Tuberculosis of the craniocervical junction J Bone Jt Surg Br 2001;83:222-5.

This pdf has been created automatically from the final edited text and images

Copyright 2012 BMJ Publishing Group. All rights reserved. For permission to reuse any of this content visit

http://group.bmj.com/group/rights-licensing/permissions.

BMJ Case Report Fellows may re-use this article for personal use and teaching without any further permission.

Please cite this article as follows (you will need to access the article online to obtain the date of publication).

Verma R, Junewar V, Garg RK, Malhotra HS. A rare case of basilar impression. BMJ Case Reports 2012;10.1136/bcr.02.2012.5851, Published XXX

Become a Fellow of BMJ Case Reports today and you can:

- Submit as many cases as you like

- Enjoy fast sympathetic peer review and rapid publication of accepted articles

- Access all the published articles

- Re-use any of the published material for personal use and teaching without further permission

For information on Institutional Fellowships contact consortiasales@bmjgroup.com

Visit casereports.bmj.com for more articles like this and to become a Fellow 